\title{
THE ESTIMATION AND RECOVERY OF DEXTRAN SULPHATES IN BIOLOGICAL FLUIDS
}

\author{
BY \\ H. A. ELLIS AND K. W. WALTON \\ From the Department of Experimental Pathology, University of Birmingham
}

(RECEIVED FOR PUBLICATION MARCH 28, 1959)

The dextran sulphates resemble heparin in being active inhibitors of several different forms of biological activity, e.g., blood coagulation, serum complement activity, and certain enzyme systems (Walton, 1954). In each case the activity of the dextran sulphate appears to be dependent upon direct interaction with one or more protein components of the biological system under investigation. In fact, the interaction of certain varieties of dextran sulphates with specific plasma proteins has been utilized as a means of plasma fractionation (Oncley, Walton, and Cornwell, 1957).

Work in this field has made it necessary to seek a simple method of assessing quantitatively the concentration of dextran sulphates of given physical and chemical characteristics in biological fluids and in some instances of recovering the dextran sulphate from these fluids. The general resemblance in chemical constitution and behaviour between the dextran sulphates and heparin suggested a survey of the published methods for the estimation and isolation of heparin to determine whether or not such methods were equally applicable to the estimation of dextran sulphates.

\section{Materials}

Dextran Sulphates.-Sulphuric esters of two different dextran fractions were prepared as previously described by Ricketts (1952). The parent dextrans had intrinsic viscosities [ $\eta$ ] of 0.04 and 0.67 respectively. The dextran sulphates derived from them contained $16.3 \%$ and $16.1 \%$ sulphur and their approximate molecular weights were I/7:7 $10^{3}$ and G.A: $2 \times 10^{6}$.

Heparin.-A commercial sample of "pularin" (Evans) was used. This sample contained $8.61 \%$ sulphur and assayed at 113 i.u./mg.

Azure A.-Batch No. 005804 of " revector" stain (Hopkins and Williams Ltd.) was used without further purification.

Thromboplastin.-Desiccated rabbit brain powder " bacto-thromboplastin" (Difco Ltd.), and acetone- extracted human brain prepared according to the method of Biggs and Macfarlane (1953) were used as specified.

Pepsin and Trypsin.-As dry powder were supplied by British Drug Houses Ltd.

Other Reagents.-Petroleum ether (B.P. $60-80^{\circ}$ C.) was supplied by May and Baker Ltd.; phenol, ammonium sulphate, and sodium chloride were employed as analytical grade reagents.

Citrated Plasma.-Whole human blood was collected from normal volunteers in a paraffined syringe and mixed with $3.8 \%(\mathrm{w} / \mathrm{v})$ sodium citrate solution in the proportions 9:1. Plasma was separated after centrifugation at 3,000 r.p.m. for 15 minutes.

\section{INTERACTION WITH BASIC DYES}

It is well known that sulphated polysaccharides react with certain basic dyes in such a way as to change the normal (orthochromatic) colour of the dye to another (metachromatic) colour. It was shown by MacIntosh (1941) that the metachromatic reaction produced by heparin when added to the basic dye, toluidine blue, could be utilized quantitatively for the estimation of this substance. Walton and Ricketts (1954) showed that the method was applicable to the estimation of dextran sulphates in aqueous solution and investigated the physico-chemical basis of the reaction. It was later found that the thiazine dye azure A, which is chemically closely similar to toluidine blue, could be employed with identical effect and was preferable in that less variation was encountered between different batches of the dye.

\section{Reagents}

(i) Azure A Solution. $-0.003 \%(w / v)$ azure $A$ in $0.01 \mathrm{~N}$ hydrochloric acid containing $0.2 \%(\mathrm{w} / \mathrm{v})$ sodium chloride.

(ii) Sodium Chloride Solution. $-0.2 \%(\mathrm{w} / \mathrm{v})$.

(iii) Dextran Sulphate Solutions. - Aqueous solutions of dextran sulphates $1 / 7$, ranging in concentration from $1 \mu \mathrm{g}$. per $\mathrm{ml}$. to $200 \mathrm{mg}$. per ml., and similar concentrations of the acid polysaccharide in citrated plasma, serum or albumin solution. 


\section{Method}

The technique used was identical with that described by Walton and Ricketts except that the azure $\mathbf{A}$ reagent was substituted for the toluidine blue reagent previously used.

\section{Results}

(i) Dextran Sulphate in Aqueous Solution.-In confirmation of the results previously obtained, as illustrated in Fig. 1 it was found that an excellent linear relationship existed between the percentage of

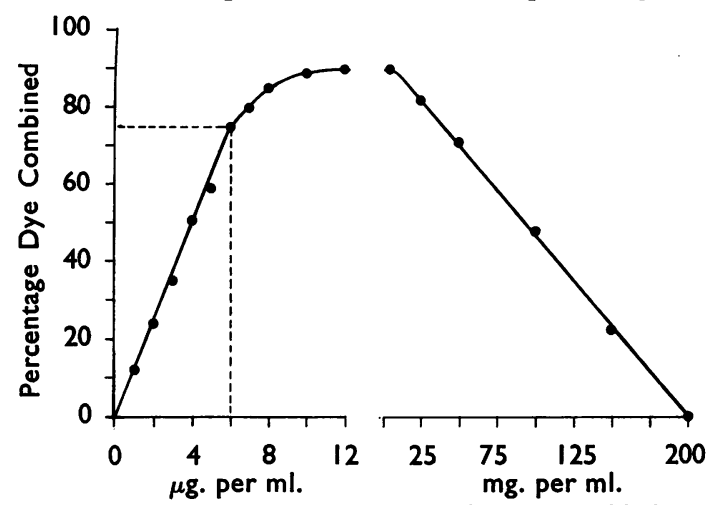

Concentration of Dextran Sulphate Added

Fig. 1.-Relationship between dextran sulphate concentration and percentage of azure $A$ combined during the production of metachromasia.

the dye bound and the concentration of dextran sulphate over the range 0 to $6 \mu \mathrm{g} . / \mathrm{ml}$. Above this range, increments in concentration of dextran sulphate produced relatively little further increase in the percentage of dye bound till a point was reached at which the latter was virtually constant over the range 12 to $5,000 \mu \mathrm{g}$. per $\mathrm{ml}$. Thereafter at still higher

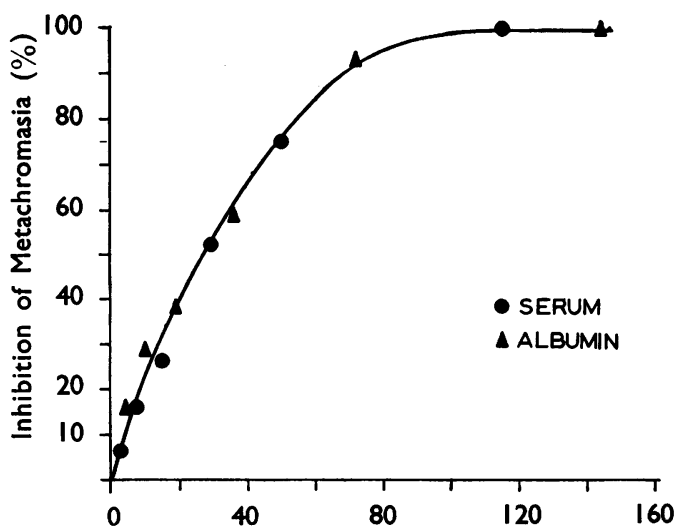

Final Concentration of Added Protein ( $\mu \mathrm{g}$. per $\mathrm{ml}$.)

FIG. 2.-Effect of proteins on the production of metachromasia (showing percentage inhibition of metachromasia given by $10 \mu \mathrm{g}$. per $\mathrm{ml}$. dextran sulphate under standard conditions by varying concentrations of protein). concentrations (5 to $200 \mathrm{mg}$. per ml.) the metachromatic reaction showed progressive inhibition, also in an apparently linear fashion.

(ii) Dextran Sulphates in Presence of Proteins.It was found that the metachromatic reaction was completely inhibited in plasma. Moreover, on attempting the extraction of the dextran sulphate-dye complex with petroleum ether a stiff viscous gel formed and no extraction was possible. Similar results were obtained when human serum or albumin solutions were substituted for plasma and as little as $0.001 \%$ of each protein produced $25 \%$ inhibition of the reaction and $0.01 \%$ protein completely masked the metachromasia (Fig. 2).

Masking of the metachromasia given by other acidic polysaccharides was similarly found by French and Benditt (1953) and by Hamerman and Schubert (1953).

\section{Evaluation}

From these results it was evident that the metachromatic method was only suitable for the estimation of dextran sulphates in "protein-free" solutions, the latter being defined as containing less than $\mathbf{0 . 0 0 0 1} \%$ protein. In such solutions the method was extremely sensitive, allowing the estimations of concentrations between 1 and $6 \mu \mathrm{g}$. per $\mathrm{ml}$. with an error of $\pm 5 \%$. It was necessary to make accurate dilutions of an unknown solution to ensure that values obtained fell upon this linear portion of the curve relating percentage of dye bound to the dextran sulphate concentration. This method has been found useful, for example, in estimating the excretion of dextran sulphates in the urine of experimental animals (Ricketts, Walton, and Saddington, 1954) and in man (Jeavons, Walton, and Ricketts, 1956) where the small amounts of protein normally present are insufficient to interfere with the production of metachromasia.

\section{ATTEMPTED RECOVERY AND ESTIMATION AFTER PROTEIN PRECIPITATION}

In view of the difficulties previously encountered, attempts were made to remove the proteins of plasma before the recovery and colorimetric estimation of dextran sulphates by the metachromatic method. Protein precipitation by a number of conventional methods (trichloracetic acid, sodium tungstate, copper tungstate, etc.) gave unsatisfactory results. Ammonium sulphate and phenol precipitations proved to be more satisfactory and are described in detail.

\section{Precipitation of Proteins with Ammonium Sulphate}

Principle.-Bassiouni (1954) used ammonium sulphate for the isolation and estimation of heparin in tissue fluids, but obtained recoveries of $50 \%$ only. Attention was therefore paid to the effects of variation of $p \mathrm{H}$, temperature, and ammonium sulphate concentration to ascertain whether or not better recoveries could be obtained. 
Reagents.-These are as follows :

Ammonium sulphate (Analar grade)

$2 \mathrm{~N}$ sodium hydroxide solution

$0.1 \mathrm{~N}$ hydrochloric acid

$0.2 \%(\mathrm{w} / \mathrm{v})$ sodium chloride solution

Buffer Reagents. $-0.2 \mathrm{M}$ disodium hydrogen phosphate and $0.1 \mathrm{M}$ citric acid

Method.-Plasma containing various amounts of dextran sulphate was added in $2.2 \mathrm{ml}$. volumes to $4.8 \mathrm{ml}$. of $0.2 \% \mathrm{NaCl}$ and $0.5 \mathrm{ml}$. $2 \mathrm{~N} \mathrm{NaOH}$, and $6.5 \mathrm{~g}$. ammonium sulphate crystals was added, the whole shaken for three minutes, allowed to stand, and then filtered. An aliquot of the filtrate was titrated against $0.1 \mathrm{~N} \mathrm{HCl}$ and the amount of acid required to neutralize the bulk of the filtrate calculated. The dextran sulphate was then estimated in the neutralized filtrate by the colorimetric method of MacIntosh. The process was repeated at a range of $p \mathrm{H}$ values from 3.75 to 12.5 (using $5.3 \mathrm{ml}$. volumes of buffer in place of $4.8 \mathrm{ml} . \mathrm{NaCl}$ and $0.5 \mathrm{ml} .2 \mathrm{~N} \mathrm{NaOH}$ ) and varying concentrations of ammonium sulphate. Protein concentrations in the various filtrates were estimated from values obtained for the optical density at 2,800 $\AA$ using a "unicam" spectrophotometer.

Results.-Small concentrations of residual protein interfered with the subsequent metachromatic reaction as expected, so that saturation with ammonium sulphate was necessary. Variations in $p \mathrm{H}$ and temperature did not significantly influence recoveries which varied from 40 to $60 \%$ of known added amounts of dextran sulphate. These results are summarized in Tables IA and IB.

TABLE IA

INFLUENCE OF AMMONIUM SULPHATE CONCENTRATION ON RECOVERY OF DEXTRAN SULPHATE

\begin{tabular}{|c|c|c|c|c|}
\hline $\begin{array}{c}\text { Percentage saturation am- } \\
\text { monium sulphate } \\
\text { Percentage protein } \\
\text { removal } \\
\text { dextran sulphate } \\
\text { recovery } \ldots\end{array}$ & $\begin{array}{l}33 \\
34 \\
\text { Nil }\end{array}$ & $\begin{array}{l}66 \\
86 \\
\text { Nil }\end{array}$ & $\begin{array}{r}100 \\
95 \\
50\end{array}$ & $\begin{array}{c}100 \\
95 \\
54 \cdot 2\end{array}$ \\
\hline
\end{tabular}

TABLE IB

RECOVERIES OF DEXTRAN SULPHATE ADDED TO PLASMA (AMMONIUM SULPHATE METHOD)

\begin{tabular}{|c|c|c|c|c|c|}
\hline \multirow[t]{2}{*}{$p \mathrm{H}$} & \multirow{2}{*}{$\begin{array}{c}\text { Concentration } \\
\text { of Added } \\
\text { Dextran } \\
\text { Sulphate } \\
\text { (mg.\%) }\end{array}$} & \multicolumn{2}{|c|}{$\begin{array}{l}\text { Concentration } \\
\text { Found } \\
(\mathrm{mg} . \%)\end{array}$} & \multicolumn{2}{|c|}{ Percentage Recovery } \\
\hline & & (a) & (b) & (a) & (b) \\
\hline $12 \cdot 5$ & $\begin{array}{c}60 \\
30 \\
15 \\
7 \cdot 5\end{array}$ & $\begin{array}{r}24 \cdot 0 \\
13 \cdot 1 \\
6 \cdot 6 \\
3 \cdot 8\end{array}$ & $\begin{array}{r}26 \cdot 4 \\
12 \cdot 0 \\
8 \cdot 6 \\
4 \cdot 2\end{array}$ & $\begin{array}{l}40 \\
43 \cdot 7 \\
44 \cdot 2 \\
50\end{array}$ & $\begin{array}{l}44 \\
40 \\
57 \\
56\end{array}$ \\
\hline $7 \cdot 0$ & 40 & \multicolumn{2}{|c|}{$\begin{array}{r}21.7 \\
3.8\end{array}$} & \multicolumn{2}{|c|}{$\begin{array}{l}54 \cdot 2 \\
50 \cdot 0\end{array}$} \\
\hline
\end{tabular}

(a) and (b) are results obtained in duplicate estimations.

\section{Precipitation with Phenol}

Principle.-Phenol added in suitable proportions to plasma produces an initial precipitation of protein which is subsequently redissolved and after standing for several hours the mixture separates into two phases, the lower containing the protein. Monkhouse and Jaques (1950) applied this property of phenol to the separation of heparin from proteins and obtained 80 to $90 \%$ recoveries of heparin added to whole blood. This principle was therefore applied to the problem of separating dextran sulphates from plasma.

Reagents.-The following were used :

A phenol solution of $800 \mathrm{ml}$. melted crystals made up to 1 litre with water

Dextran sulphate $(I / 7)$ dissolved in human plasma in concentrations from $3.75 \mathrm{mg}$. to $200 \mathrm{mg}$. \%

Ether and $0.85 \%$ saline $(\mathrm{w} / \mathrm{v})$

Method.-Dextran sulphate in plasma was added in $5 \mathrm{ml}$. volumes to $5.5 \mathrm{ml}$. volumes of phenol solution and allowed to stand 10 to 12 hours after vigorous mixing. The tubes were then centrifuged and the clear upper layer pipetted off. The remaining phenol layer was washed with saline and the washings added to the aqueous layer. The combined aqueous phase was washed with $5 \mathrm{ml}$. ether which was then pipetted off. The residual ether was evaporated by heating at $65^{\circ} \mathrm{C}$. for a few minutes on a waterbath. The dextran sulphate in the aqueous phase thus obtained was estimated colorimetrically by the metachromatic reaction.

Results.-The dextran sulphate separated from protein in the aqueous phase and estimated colorimetrically gave values indicating recoveries of approximately 75 to $95 \%$ of added dextran sulphate. Examples of recoveries at various dextran sulphate concentrations dissolved in plasma are given in Table II. Duplicate results were reproducible with an error of $\pm 5 \%$.

\section{TABLE II}

RECOVERY OF DEXTRAN SULPHATE FROM PLASMA (PHENOL METHOD)

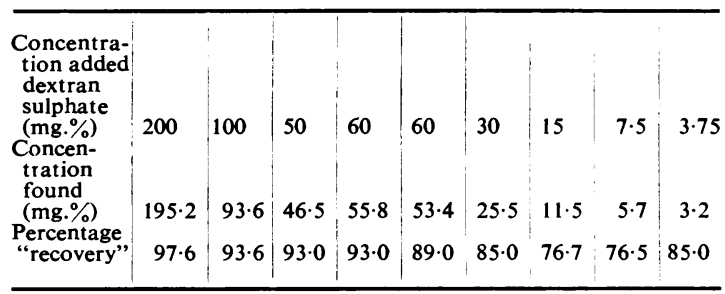

Evaluation of Protein Precipitation.-Ammonium sulphate precipitation was less time-consuming than phenol precipitation but had the obvious disadvantage of low recoveries of dextran sulphate added to plasma and interference with the metachromatic reaction unless protein precipitation was virtually complete. The phenol method gave good and reproducible recoveries and there was no interference subsequently with the metachromatic reaction. Attempts to reduce the time of standing allowed in this method to periods varying between one and six hours gave unsatisfactory recoveries of from 45 to $75 \%$. 


\section{ATTEMPTED PRELIMINARY DIGESTION OF PROTEIN \\ Principle}

Harington, Pochin, and Squire (1940) reported the prevention of protein interference during the estimation of Evans blue in plasma by preliminary digestion with pepsin. In the present context digestion was attempted with pepsin and trypsin.

\section{Reagents}

The following were used:

Pepsin, 5\% (w/v) aqueous solution

Trypsin, $5 \%(\mathrm{w} / \mathrm{v})$ aqueous solution

Hydrochloric acid, $5 \mathrm{~N}$

Sodium hydroxide, $5 \mathrm{~N}$

Dextran sulphate $I / 7$ dissolved in plasma

Sodium chloride solution, $0.2 \%(\mathrm{w} / \mathrm{v})$

\section{Method}

Pepsin solution, $0.4 \mathrm{ml}$., was added to $2 \mathrm{ml}$. plasma to which dextran sulphate had been added in concentrations from 2 to $60 \mathrm{mg} . \%$. The $p \mathrm{H}$ was adjusted to 1.7 by the addition of $0.20 \mathrm{ml} .5 \mathrm{~N} \mathrm{HCl}$, before incubation for three hours at $40^{\circ} \mathrm{C}$. Then $0.2 \mathrm{ml}$. $5 \mathrm{~N} \mathrm{NaOH}$ was added to bring the $p \mathrm{H}$ to 3.5 and the volume was made up to $20 \mathrm{ml}$. using $0.2 \% \mathrm{NaCl}$. Aliquots were used for the colorimetric estimation of dextran sulphate using the metachromatic reaction.

\section{Results}

Protein digestion did not occur in the presence of dextran sulphate, whereas in control plasma samples free from dextran sulphate it proceeded satisfactorily. Dextran sulphate was not detected subsequently by the metachromatic reaction. Trypsin was used at $p \mathrm{H} 8.5$ and again no digestion occurred.

\section{Evaluation}

Clearly, preliminary digestion of protein with pepsin or trypsin is unsatisfactory as these enzymes appear to be inhibited by dextran sulphate. This was confirmed by the observation that dextran sulphate produced a diminution of the area of haemoglobin denaturation by trypsin on a blood agar plate. Dextran sulphate therefore resembles heparin, which was shown to inhibit tryptic digestion by Horwitt (1940). Papain was found to be equally unsatisfactory for the same reason. Furthermore, using azo-albumin as substrate (Tomarelli, Charney, and Harding, 1949), it was found that dextran sulphate inhibited the proteolytic activities of crystalline preparations of trypsin and chymotrypsin.

\section{ESTIMATION OF DEXTRAN SULPHATE IN PLASMA BY VIRTUE OF ITS ANTICOMPLEMENTARY ACTIVITY}

Heparin and other highly charged macromolecular compounds are known to exert an anticomplementary effect in a haemolytic system (Ecker and Gross, 1929). Walton, Ellis, and Taylor (1957) have described a method for the determination of the anticomplemen- tary activity of heparin and dextran sulphates. Attempts to utilize this technique for the estimation of dextran sulphate were satisfactory for saline solutions but for solutions in plasma unreliable results were obtained, due presumably to the occasional anticomplementary activity of plasma and interference by citrate ions.

\section{ESTIMATION OF DEXTRAN SULPHATE BY VIRTUE OF ITS ANTITHROMBOPLASTIC ACTIVITY \\ Principle}

It was known that dextran sulphate inhibited "thromboplastin activity" and recently Grasset and Schwartz (1955) described a method of assay for heparin and dextran sulphate based upon this fact.

\section{Reagents}

The following were used:

Fresh citrated human plasma

Thromboplastin suspension in saline

Calcium chloride solution $\mathrm{M} / 40$

Dextran sulphate solutions $\mathrm{I} / 7$ and G.A in graded concentrations dissolved in saline, serum, or plasma

\section{Method}

Plasma, $0.1 \mathrm{ml}$, and $0.1 \mathrm{ml}$. of thromboplastin were added to $0.2 \mathrm{ml}$. of dextran sulphate solution and allowed to stand for 10 minutes at room temperature. Then $0.1 \mathrm{ml}$. $\mathrm{M} / 40 \mathrm{CaCl}_{2}$ was added on a water-bath at $37^{\circ} \mathrm{C}$. and the clotting time recorded. Triplicate estimations were made for each concentration of dextran sulphate.

Standard curves were constructed relating the clotting times obtained to the corresponding dextran sulphate concentrations. Values for unknown samples were obtained by reference to these curves.

\section{Results}

The low molecular weight dextran sulphate (I) gave an apparent linear relationship between clotting times and concentration of added material (Fig. 3). In order to test the validity and reproducibility of this, three runs were made in triplicate over the range 0 to $10 \mu \mathrm{g}$. per $0.2 \mathrm{ml}$. added dextran sulphate solution, using the same substrate plasma and the same batch of thromboplastin. Analysis of the data obtained revealed a significant regression coefficient in each case with no significant difference between the slopes of individual runs. Ninety-five per cent. confidence

TABLE III

REPRODUCIBILITY OF ESTIMATION OF DEXTRAN SULPHATE BY THROMBOPLASTIN METHOD

\begin{tabular}{|c|c|c|c|c|}
\hline & $\underset{1}{\text { Run }}$ & $\underset{2}{\text { Run }}$ & $\underset{3}{\text { Run }}$ & $\begin{array}{l}\text { Common } \\
\text { Regression }\end{array}$ \\
\hline $\begin{array}{lr}\begin{array}{l}\text { Regression } \\
\text { cient }(r)^{*}\end{array} & \text { coeffi- } \\
\text { Slope (b) } & \ldots\end{array}$ & $\begin{array}{l}0.969 \\
0.50\end{array}$ & $\begin{array}{l}0.972 \\
0.54\end{array}$ & $\begin{array}{l}0.951 \\
0.60\end{array}$ & $\begin{array}{l}0.959 \\
0 \cdot 54\end{array}$ \\
\hline $\begin{array}{l}\text { Degrees freedom } \\
\text { (n-2) } \\
\text { Significance (P) }\end{array}$ & $\begin{array}{c}13 \\
>0.001\end{array}$ & $\begin{array}{l}13 \\
>0.001\end{array}$ & $\begin{array}{l}13 \\
>0.001\end{array}$ & $\stackrel{43}{>0.001}$ \\
\hline
\end{tabular}

* Derived from regression lines relating clotting time to concentration of added dextran sulphate. 
limits were calculated for the common regression line and the experimental points, with few exceptions, fell within these limits (Table III and Fig. 4). Results varied when different batches of thromboplastin were used and it was necessary to construct a standard curve for any given set of reagents.
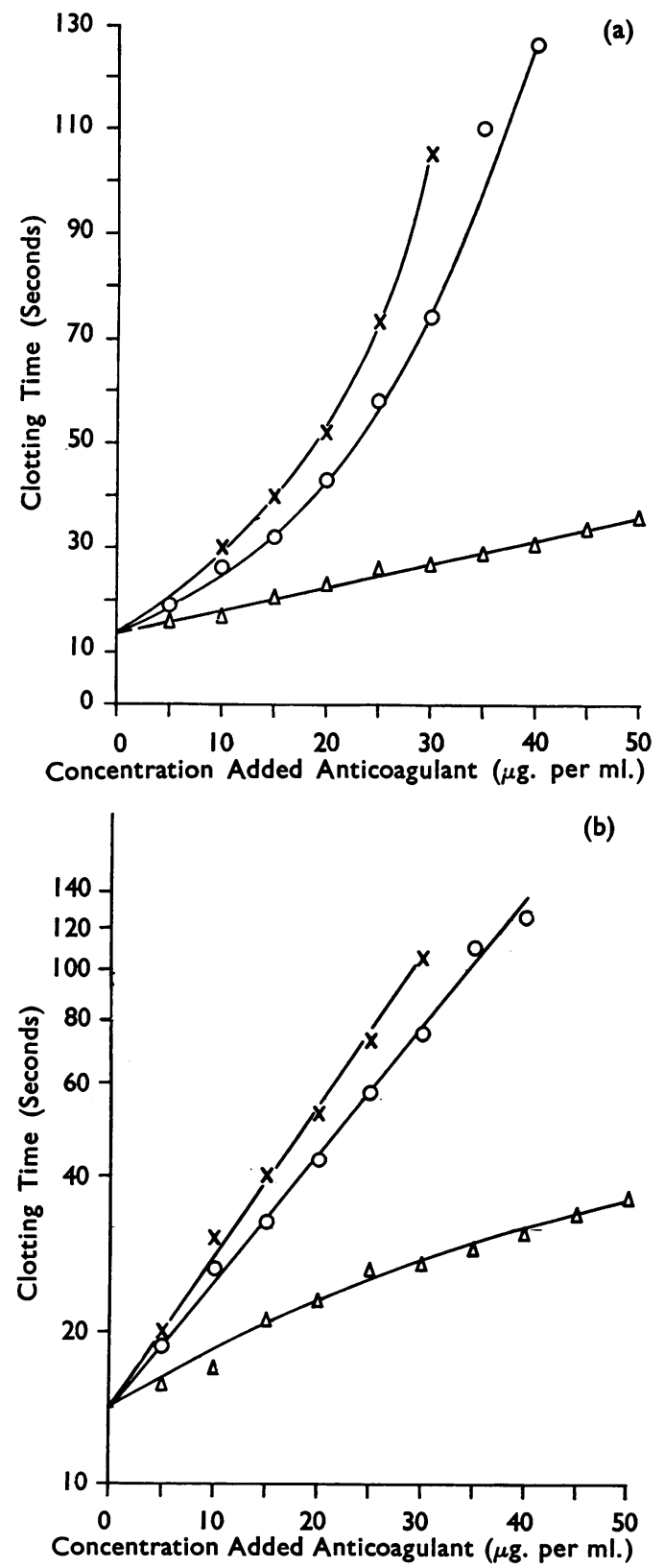

Fig. 3.-Antithromboplastic activity of heparin and dextran sulphates. (Note the use of logarithmic spacing on ordinate in $3 \mathrm{~b}$.) $X \longrightarrow X$ heparin, $\mathbf{O}-\mathbf{O}$ dextran sulphate (G.A), $\Delta-\Delta$ dextran sulphate (I).

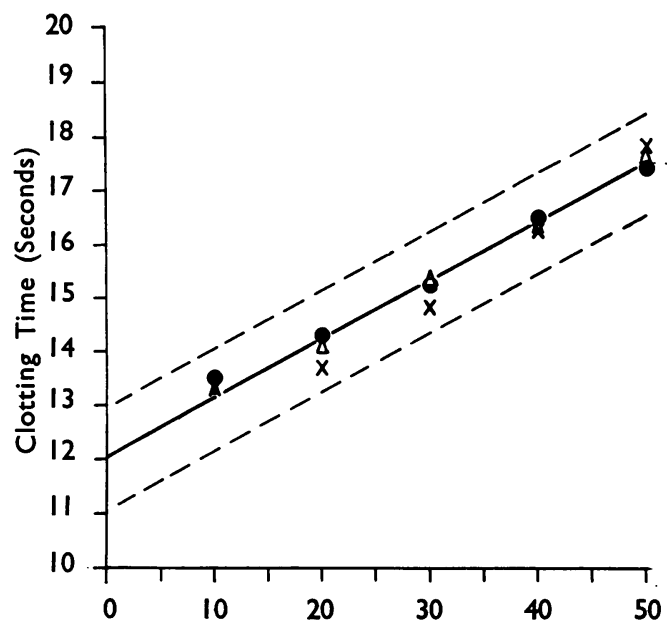

Concentration of Dextran Sulphate ( $\mu \mathrm{g}$. per $\mathrm{ml}$.

Fig. 4.-Antithromboplastic activity of dextran sulphate (I). Solid line: common regression for three runs. Interrupted line: $95 \%$ confidence limits for common regression. $\bullet, \Delta$, and $X$ : mean experimental points for runs 1,2 , and 3 respectively.

In the case of the large molecular weight dextran sulphate (G.A) and heparin, a curvilinear relationship was obtained (Fig. 3). This could be transformed to a linear one by plotting the logarithm clotting time against concentration of added material (Fig. 3), thus facilitating the assessment of test solution values by reference to the standard curves.

It was observed that when very low (less than $1 \mu \mathrm{g}$. per $0.2 \mathrm{ml}$.) concentrations of dextran sulphate were added to the system there was an apparent . pro-thromboplastic effect in that there was a shortening of the base line clotting time. From these observations it was apparent that for the estimation of unknown concentrations of dextran sulphate in aqueous or protein solutions it was necessary to make several dilutions in saline to ensure a final concentration within the range of 2 to $10 \mu \mathrm{g}$. per $0.2 \mathrm{ml}$. of added solution. In practice it was found to be convenient to take the mean of the values obtained for two consecutive dilutions which fell within this range. The results of estimations of various concentrations of dextran sulphate $(I / 7)$ in the presence of protein are illustrated in Table IV.

With concentrations less than $0.004 \%$ of dextran sulphate in plasma unreliable results are obtained as the added neat or only slightly diluted plasma upsets the concentration of citrate ions, fibrinogen, prothrombin, and accessory clotting factors in the system.

\section{TABLE IV}

PERCENTAGE ERROR OF DEXTRAN SULPHATE ESTIMATION BY THROMBOPLASTIN METHOD

\begin{tabular}{|c|c|c|c|c|c|c|c|}
\hline $\begin{array}{l}\text { Concentration added } \\
\text { dextran sulphate } \\
\text { (mg.\%) } \% \\
\text { Estimated concentra- }\end{array}$ & 200 & 200 & 100 & 50 & 25 & 10 & 5 \\
\hline $\begin{array}{ll}\text { tion (mg.\%) } & \\
\text { Error percentage } & \ldots\end{array}$ & $\begin{array}{l}212 \cdot 5 \\
+6\end{array}$ & $\begin{array}{r}200 \\
0\end{array}$ & $\begin{array}{r}90 \\
-10\end{array}$ & $\begin{array}{r}54 \\
+8\end{array}$ & $\begin{array}{r}29 \\
+16\end{array}$ & $\begin{array}{c}9 \cdot 5 \\
-5\end{array}$ & $-10^{4 \cdot 5}$ \\
\hline
\end{tabular}




\section{Evaluation}

The method provides a reasonable estimate of dextran sulphate in aqueous solution detecting as little as $0.0005 \%$ and requiring only $0.6 \mathrm{ml}$. for triplicate observations. In the presence of plasma the method is still valid down to $0.004 \%$ dextran sulphate. It is primarily a method for the estimation of dextran sulphate in the presence of protein and no recovery of the material is possible. It has the disadvantage that estimates at various dilutions may be necessary in order to obtain a concentration somewhere within the range 2 to $10 \mu \mathrm{g}$. per $0.2 \mathrm{ml}$.

\section{DISCUSSION}

The estimation of acidic polysaccharides in "protein-free" solution presents little difficulty and can be undertaken readily using MacIntosh's (1941) method which measures the proportion of basic dye bound with polysaccharide. As already mentioned, the method is therefore applicable to the estimation of dextran sulphate in urine. In the presence of proteins, however, the intensity of the metachromatic reaction may be masked partly or completely on account of dye-protein competition. Furthermore, the protein interferes with the separation of the residual dye from the metachromatic complex on addition of petroleum ether, as a stiff viscous gel is produced.

Prevention of the protein interference by preliminary enzymic digestion was not possible, but the interesting fact was revealed that dextran sulphates inhibited the activities of trypsin and pepsin and thus resembled heparin (Horwett, 1940). Attempts to separate the dextran sulphates from protein before estimation in aqueous solution by preliminary precipitation of the proteins revealed that the usual protein precipitants such as trichloracetic acid were valueless. However, ammonium sulphate precipitation gave approximately $50 \%$ and the phenol method approximately $95 \%$ recoveries respectively, of known amounts of dextran sulphate added to plasma. The latter method had the disadvantage of being time-consuming, but gave consistently good recoveries and was the method of choice where actual recovery of dextran sulphate or an accurate estimate of concentration was required.

When it was necessary to obtain an approximate estimation of dextran sulphate concentration in the presence of protein, and where actual recovery of material was not of importance, the modified one-stage prothrombin technique was useful. Results were not so precise as those obtained with the phenol method. Nevertheless, this method was found to be useful for routine laboratory use where many approximate estimates of dextran sulphate were required in a short period.

The "prothromboplastin effect" of dextran sulphate in low concentrations noted here has also been reported by Forwell and Ingram (1956). They considered that it was due to an acceleration of the interaction between Factors V and VII and brain thromboplastin. This aspect has also recently been discussed by Hjört and Stormorken (1957).

\section{SUMMARY}

Estimations of dextran sulphates in "proteinfree" solution were made accurately by MacIntosh's colorimetric method which depends upon the production of metachromasia with certain basic dyes. Traces of plasma proteins or isolated serum albumin were found to invalidate this technique. Attempts to remove plasma proteins by preliminary protein precipitation or enzyme digestion were not satisfactory. Precipitation with phenol was found to remove protein most efficiently and allowed the dextran sulphate to be recovered almost completely. Two methods for estimating dextran sulphate, whilst still in the presence of protein, were tested: the first, based upon measurement of the anticomplementary activity, was unsatisfactory; the second, based upon measurement of the antithromboplastin activity, proved useful where a rapid, but approximate, answer was required.

Our thanks are due to Dr. C. R. Ricketts, who supplied the dextran sulphates, Mr. M. Hall for analytical data on the heparin, and Professor J. R. Squire for helpful criticism. One of us (H. A. E.) was in receipt of a research grant from the United Birmingham Hospitals Endowment Fund.

\section{REFERENCES}

Bassiouni, M. (1954). J. clin. Path., 7, 330.

Biggs, R., and Macfarlane, R. G. (1953). Human Blood Coagulation and its Disorders. Blackwell Scientific Publications, Oxford.

Ecker, E. E., and Gross, P. (1929). J. infect. Dis., 44, 250.

Forwell, G. D., and Ingram, G. I. C. (1956). J. Pharm. (Lond.), 8,

French, J. E., and Benditt, E. P. (1953). J. Histochem. Cytochem., 1,321 .

Grasset, E., and Schwartz, D. E. (1955). Brit.J. Pharmacol., 10, 317.

Hamerman, D. J., and Schubert, M. (1953). J. gen. Physiol., 37, 291.

Harington, C. R., Pochin, E. E., and Squire, J. R. (1940). Clin. Sci., 4, 311 .

Hjört, P., and Stormorken, H. (1957). Scand. J. clin. Lab. Invest., 9, Suppl. 29.

Horwitt, M. K. (1940). Science, 92, 89.

Jeavons, S. M., Walton, K. W., and Ricketts, C. R. (1956). Brit. med. J., 2, 1016.

MacIntosh, F. C. (1941). Biochem. J., 35, 776.

Monkhouse, F. C., and Jaques, L. B. (1950). J. Lab. clin. Med., 36, 782.

Oncley, J. L., Walton, K. W., and Cornwell, D. G. (1957). J. Amer. chem. Soc., 79, 4666.

Ricketts, C. R. (1952). Biochem. J., 51, 129.

Ricketts, C. R. (1952). Biochem. J., 51, 129.

Tomarelli, R. M., Charney, J., and Harding, M. L. (1949). J. Lab. clin. Med., 34, 428.

Walton, K. W. (1954). Brit. J. Pharmacol., 9, 1.

Elis, H. A., and Taylor, C. E. D. (1957). Brit. J. exp. Path., 38, 237.

and Ricketts, C. R. (1954). Ibid., 35, 227. 